\begin{tabular}{c}
\hline The women of \\
a higher class are \\
waiting to have a \\
tooth inserted into \\
their sockets. Poorer \\
people often had \\
healthier teeth because \\
they did not have \\
access to the luxury \\
of sugar. \\
\hline
\end{tabular}

colours and the relaxed positioning of the patient. The painting features the dental X-ray machine. John Lavery was one of the 'Glasgow Boys' - a group of artists based in Glasgow from 1870 until the 1900s. They were influenced by French realist paintings and aimed to raise the standards of Scottish painting. ${ }^{6-10}$

Rebecca and Lorna would like to thank Mrs Laetitia Brocklebank, Ms Rachel Bairsto, Dr Josephine Cummins, Mr Thomas Elliot, Professor David A. McGowan, Mrs Orla O'Donnell, Dr Maureen Park, Mrs Melanie Parker and Dr Rufus $M$. Ross for all their assistance with this project.

1. Ring M E. Dentistry - an illustrated history. p 166. Harry N. Abrams, Inc, 1992.

2. Pindborg J J, Marvitz L. The dentist in art. p 96. Quadrangle Books, 1960.

3. Hillam C (ed). The roots of dentistry: for the Lindsay Society and for the history of dentistry. p 21. London: British Dental Association, 1990

4. British Dental Association website. Transplanting of teeth. Available at: www.bda.org/museum/collections/ dental-art/transplanting-of-teeth.aspx (accessed 27 January 2014).

5. Trevers J, Orskey M. Open wide! A series of eighteenth and nineteenth century caricatures on dentistry. Wychwood Books, 2009.

6. Discussions with Dr Maureen Park and Professor David McGowan.

7. McConkey K. Sir John Lavery's The Dentist (Conrad Ackner and his Patient). Br Dent J 2011; 210: 81-85.

8. British Dental Association website. The dentist. Available at: www.bda.org/ museum/collections/dental-art/thedentist.aspx (accessed 27 January 2014).

9. Hillam C (ed). The roots of dentistry: for the Lindsay Society and for the history of dentistry. p 18. London: British Dental Association, 1990.

10. Menzies Campbell J. Articles on Menzies Campbell Collection - Dental Pictures (articles reprinted from The Dental Magazine and Oral Topics June 1964).
BOOK REVIEW

ORAL IMPLANTS: BIOACTIVATING CONCEPTS

\begin{tabular}{|c|c|}
\hline ORAL IMPLANTS & $\begin{array}{l}\text { E. Ewers, } \\
\text { J. T. Lambrecht }\end{array}$ \\
\hline$\equiv$ & $\begin{array}{l}\text { Quintessence } \\
\text { price } £ 198.00 \text {; pp } 500\end{array}$ \\
\hline & $\begin{array}{l}\text { ISBN } \\
9781850972334\end{array}$ \\
\hline
\end{tabular}

This is the second textbook from these editors and promises to be a must-have textbook providing a comprehensive synopsis of the current evidence-based understanding of perio-implant prosthesis; it does not fail to deliver.

The text is divided into six comprehensive chapters, starting with basic principles and then follows the logical progression through clinical planning and techniques, with the final chapter covering the range of complications associated with the provision of perio-implant prostheses. Each chapter is subsequently sub-divided into bite sized sub-categories to allow easy digestion of what may be an otherwise overwhelming sea of information.

The first chapter Basic principles is an in-depth review of bone and soft tissue physiology. These chapters form the minimum foundation knowledge required in implantology. Although these first chapters are heavily science-based, they are perfectly balanced with explanatory colour illustrations, clinical photographs, radiographs and histopathological slides to keep the reader engaged.

The second chapter Clinical planning takes the reader through the logical thought-process when considering each case and is complemented well with the fourth chapter Standard clinic situations. The multiple clinic situations outlined come complete with step-bystep clinical photography of the surgical techniques, radiographic examinations and before-and-after pictures.

A full chapter is dedicated to bone regeneration techniques and classifications and does its best to keep the reader's attention with corresponding CTs, radiographs and photos.

Although interesting, the complex clinical situations outlined in Special techniques are very unlikely to be encountered outside of specialised hospital-based departments and are there merely for completeness. Finally Complications highlights the common complications likely to be encountered throughout your implantology career and is a valuable read.

In all, this text is a must-have adjunct to the reading material for anyone undertaking further postgraduate training in implantology. The textbook has a surgical focus but provides an excellent knowledge foundation within its first chapter. Each evidence-based chapter is extensively referenced with the current literature and thinking. The authors claim 'In short this book is a must!' and in this case I am inclined to agree.

J. DOCHERTY

\section{HPV HOME TESTS COULD SPOT CANCER RISK}

HPV (human papillomavirus) self-testing is as effective as tests carried out by doctors, according to research from Sweden. ${ }^{1}$ Simple HPV home tests could complement existing screening programmes, and identify more women at risk of cervical cancer.

HPV is also a cause of oropharyngeal cancers and cancers of the anus, vulva and penis.

Like the UK, Sweden has a system of regular gynaecological smear tests, which has halved the number of cases of cervical cancer. Most of the patients who die from the disease are either above the screening age, or part of the $20 \%$ who fail to attend their screenings. The figures are similar in other countries with equivalent screening programmes.

Study author Dr Lotten Darlin, of Lund University, said: 'We are usually able to cure cases of cancer that are identified through smear tests. For those women who have not been for smear tests, the cancer has progressed considerably further by the time it is diagnosed. It is these women who are at risk of dying from the disease'.

Dr Darlin investigated the possibility of home testing, but found that the testing kits available were either complicated or expensive. Her team developed their own test comprising a cotton bud and a test tube. The test is sent off to a lab, where it has been shown

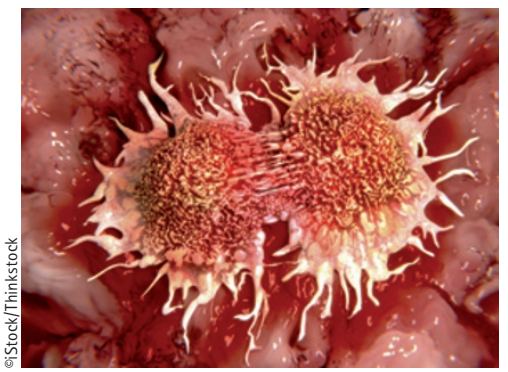

to produce just as clear results as HPV tests taken by a doctor.

In one study, self-testing kits were sent to 1,000 women who had not had a smear test for over nine years. Fifteen percent of them used the test and sent in samples for analysis.

Dr Darlin believes that the simple self-testing kit could also be used in countries that do not have a programme of regular cervical smear tests.

1. Darlin L. Cervical cancer: studies on prevention and treatment. Faculty of Medicine, Lund University, Sweden: Doctoral Dissertation. 2013. 